\title{
Hemostatic Abnormalities in COVID-19: An Update
}

\author{
Mukul Aggarwal $^{1} \cdot$ Jasmita Dass $^{1}$ (D) Manoranjan Mahapatra $^{1}$
}

Received: 23 May 2020/Accepted: 3 August 2020/Published online: 11 August 2020

(C) Indian Society of Hematology and Blood Transfusion 2020

\begin{abstract}
COVID-19 has emerged as a pandemic with lung being the primarily afflicted organ. Deranged hemostasis has been observed in patients with COVID-19 with scales tipped towards a prothrombotic state. The pathogenesis differs from disseminated intravascular coagulation with a primary pulmonary localization. This is referred to as pulmonary intravascular coagulopathy with strong component of thrombo-inflammation. This is reflected in the lab tests with an increase in D-dimer which correlates with severity and outcomes of disease. Common coagulation tests such as prothrombin time, activated partial thromboplastin time are only mildly prolonged while most patients have normal to increased fibrinogen and marginal thrombocytopenia. Overall, the patients have an increase in venous and arterial thrombotic events especially in ICU patients. Routine thromboprophylaxis with low molecular weight heparin is recommended in all hospitalized patients to reduce the incidence of thrombosis. Bleeding is uncommon and treated with blood products transfusion. This review shall discuss the hemostatic abnormalities in COVID-19 patients and their impact on prognosis. In addition, strategy of thromboprophylaxis and various academic society guidelines are discussed in detail.
\end{abstract}

Jasmita Dass

drjasmita@gmail.com

Mukul Aggarwal

mukulmamc@gmail.com

Manoranjan Mahapatra

mrmahapatra@hotmail.com

1 Department of Hematology, All India Institute of Medical Sciences, New Delhi, New Delhi, India
Keywords COVID-19 - COVID associated coagulopathy · D-dimer · Thrombosis · Pulmonary intravascular coagulopathy

\section{Introduction}

COVID-19, the novel coronavirus infection started from Wuhan, China in December 2019. The outbreak was declared a public health emergency of international Concern on 30 January 2020 and later a pandemic on March 11, 2020 by World Health Organization (WHO) [1]. It is caused by the severe acute respiratory syndrome coronavirus 2 (SARS-CoV-2). This virus belongs to the $\beta$ Coronavirus family and is partially like the SRS-CoV and MERS-CoV coronaviruses which have caused previous epidemics in China and Middle East respectively [2]. The management of the disease is challenging as the virus is highly infectious and there is a large burden of asymptomatic patients, absence of proven antiviral drugs, and limited understanding of potential benefits from antiviral antibodies [3].

Severe Acute Respiratory Distress Syndrome (ARDS), in addition progression to multi-organ dysfunction syndrome has been recognized as cause of death in most of the patients. ARDS is common amongst patients needing hospitalization, which comprise around $20 \%$ of all infected patients [4]. The exact mechanism of pulmonary complications and ARDS of COVID-19 has not been elucidated but there is a clear component of thrombo-inflammation and cytokine storm [5, 6].

Irrespective of the cause of sepsis, coagulopathy is consistently associated with poor prognosis [7] and this has been postulated for COVID-19 as well. Multiorgan dysfunction is likely in coagulopathy in patients with sepsis 
and leads to increased mortality. Multiple reports have reported the presence of deranged parameters of coagulation in patients of COVID-19. In this review, we will discuss the various pathophysiological mechanisms leading to COVID-19 associated coagulopathy (CAC), derangement in laboratory parameters, incidence, and risk factors of venous thromboembolism (VTE) and prevention and treatment of CAC.

\section{Pulmonary Intravascular Coagulation, its Histopathological Evidence and Contribution of Cytokine Storm}

COVID-19 patients have been shown to have high levels of D-dimer $[8,9]$ but unlike patients of sepsis, they only have a mild prolongation of prothrombin time (PT), activated partial thromboplastin time (APTT), mild thrombocytopenia $[4,9]$. The first histopathology report was incidental in two lung cancer patients with unsuspected COVID-19. Lung histopathology revealed only early findings seen in COVID-19 including alveolar damage with proteinaceous alveolar exudates and edema, vascular congestion, and focal fibrin deposition with pneumocyte hyperplasia [10]. These findings suggested that pulmonary coagulopathy starts early in the disease itself. Mortality has been reported right from the beginning but the autopsy data from COVID-19 patients has lagged. Till date, very few studies on histopathological findings are available [11-15].

Autopsy data suggests that there is exudative diffuse alveolar damage with severe capillary congestion. In addition, the frequent findings include edema, alveolar hemorrhage, pulmonary embolism and microthrombi in the alveolar capillaries [11].

These findings were aptly described by McGonagle as Pulmonary intravascular coagulation (PIC) with the suggestion that it arises due to macrophage activation syndrome (MAS)-like intrapulmonary inflammation that causes vessel wall damage [16]. This PIC is mediated by a thrombo-inflammation. SARS-CoV2 infects the type II pneumocytes via angiotensin converting enzyme 2 (ACE2) receptors eliciting a phenomenon culminating in PIC (Fig. 1). Due to the widespread presence of ACE-2 receptor in the lung, there is a damage to large surface area of the alveoli leading to hypoxemia. In addition, there is extensive vascular damage due to juxtaposition of type II pneumocytes to the vessels. The infection also causes a massive cytokine storm. There is increased expression of tissue factor on endothelium and inflammatory cells including neutrophils and macrophages. There is extensive endothelial injury and dysfunction partly due to cytokines such as interleukin (IL)-1, IL-6 and tumour necrosis factor$\alpha$ as well as an intra-pulmonary MAS-like inflammation.
These phenomena ultimately lead to intrapulmonary activation of coagulation cascade. Inflammatory reaction also caused a reduced level of plasminogen activator inhibitor-1 (PAI-1) causing increased level of plasmin. There is both a component of intrapulmonary thrombosis, microhemorrhages and hyperfibrinolysis. Plasmin and other proteases can also cleave a furin site in the S protein of SARS-CoV 2 leading to increased virulence of the virus. Thrombosis observed is primarily intra-pulmonary but can progress to systemic thrombosis in a subset of patients. The combination of thrombosis and inflammation cause a positive feedback loop exacerbated by local hypoxia [16].

Magro et al. [12] examined skin and lung tissues from 5 patients. According to them, the pattern of COVID-19 pneumonitis was predominantly a pauci-inflammatory septal capillary injury with significant septal capillary mural, luminal fibrin deposition and permeation of the interalveolar septa by neutrophils. No viral cytopathic changes were observed and the diffuse alveolar damage (DAD) with hyaline membranes, inflammation, and type II pneumocyte hyperplasia, the hallmarks of classic ARDS were not prominent. Significant deposits of terminal complement components C5b-9 (membrane attack complex), $\mathrm{C} 4 \mathrm{~d}$, and mannose binding lectin (MBL)-associated serine protease (MASP), in the microvasculature were seen consistent with sustained, systemic activation of the alternative and lectin-based complement pathways. Purpuric skin lesions similarly showed a pauci-inflammatory thrombogenic vasculopathy, with deposition of C5b-9 and C4d. There was co-localization of COVID-19 spike glycoproteins with C4d and C5b-9 in the interalveolar septa and the cutaneous microvasculature [12].

Histological similarities were observed between COVID 19 and SARS 2002-2003. Localized pulmonary hemorrhage, pulmonary edema, desquamation with hyaline membrane formation and an interstitial mononuclear inflammatory infiltrate were seen. Localized pulmonary arteriolar thrombosis was seen with SARS but not with COVID-19 [13].

Wichmann and colleagues described autopsy findings in 12 COVID-19 patients revealing deep venous thrombosis (DVT) in 7 of 12 unsuspected patients (58\%). Pulmonary embolism (PE) was the direct cause of death in 4 patients. Histologically, DAD was seen in 8 patients. In all patients, SARS-CoV-2 RNA was detected in lungs at high concentrations; viremia in 6 of 10 and 5 of 12 patients demonstrated high viral RNA titers in the liver, kidney, or heart [14]. Immunohistochemistry done on lung specimens revealed thickened alveolar capillaries with edema and fibrin thrombi. There were CD61 and von Willebrand factor ( $\mathrm{vWF}$ ) positive resident pulmonary megakaryocytes in alveolar capillaries that exhibited nuclear hyperchromasia and atypia [15]. 


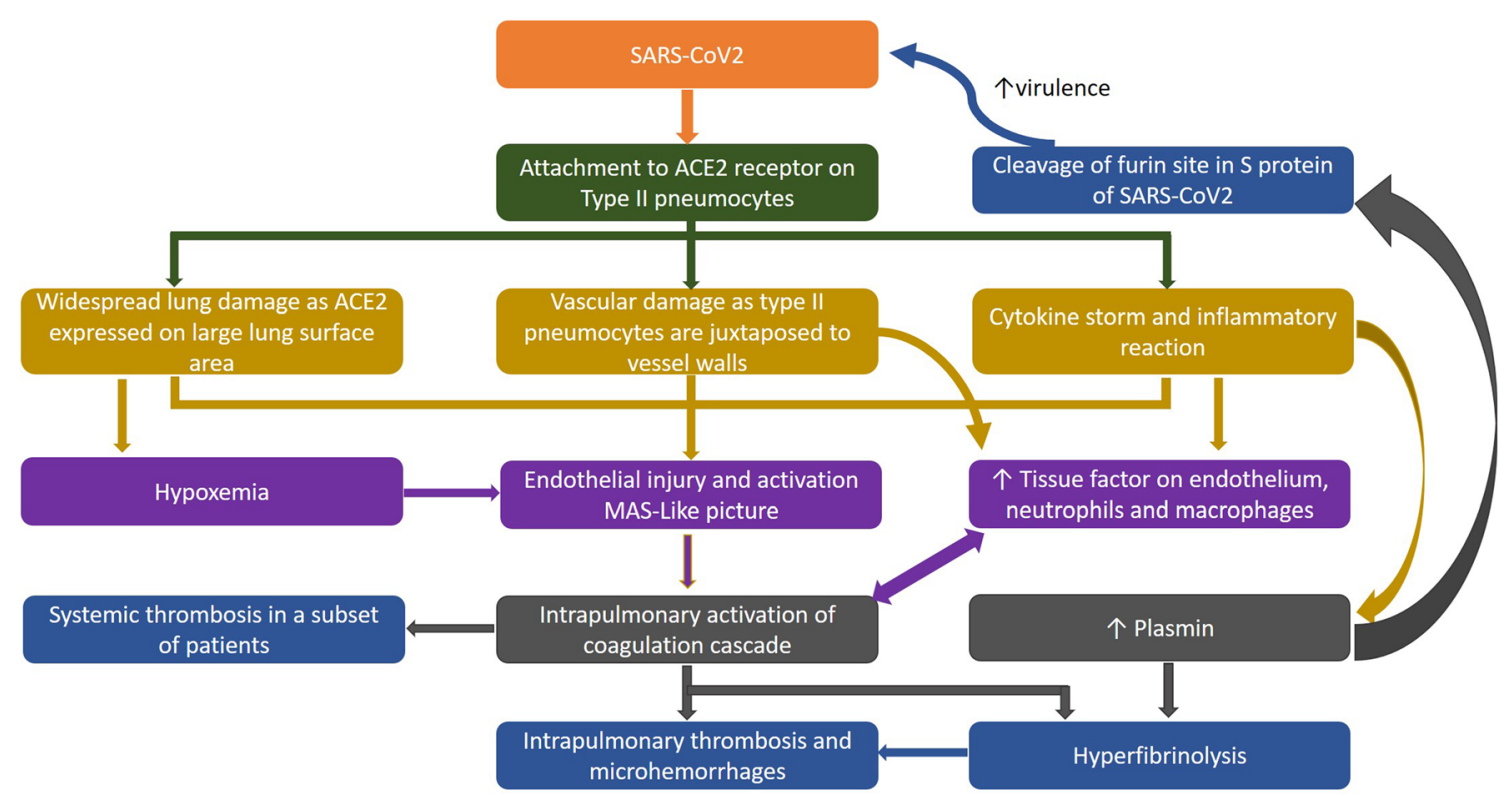

Fig. 1 Pathogenesis of pulmonary intravascular coagulopathy (PIC) and thrombosis

\section{Coagulation Abnormalities}

Overall COVID-19 is associated with a hypercoagulable state with DIC setting in only in late cases. Coagulation anomalies and clinical features observed in COVID-19 associated coagulopathy are different from DIC (Fig. 2). DIC can complicate the course of disease with reported incidence of $71.4 \%$ in non-survivors when compared to only $0.6 \%$ survivors [8]. While DIC predominantly presents with generalized derangement of coagulation and bleeding manifestations, CAC has specific alterations in these coagulation parameters that differ from DIC and clinical bleeding is uncommon.

\section{Platelet Pounts (PC)}

Thrombocytopenia has been observed in $~ 18-36 \%$ of hospitalized patients with COVID-19 but is usually not severe $[9,17,18]$. PC of $<100 \times 10^{9} / \mathrm{L}$ is seen in only $5 \%$ COVID-19 patients [4]. COVID-19 patients have a higher
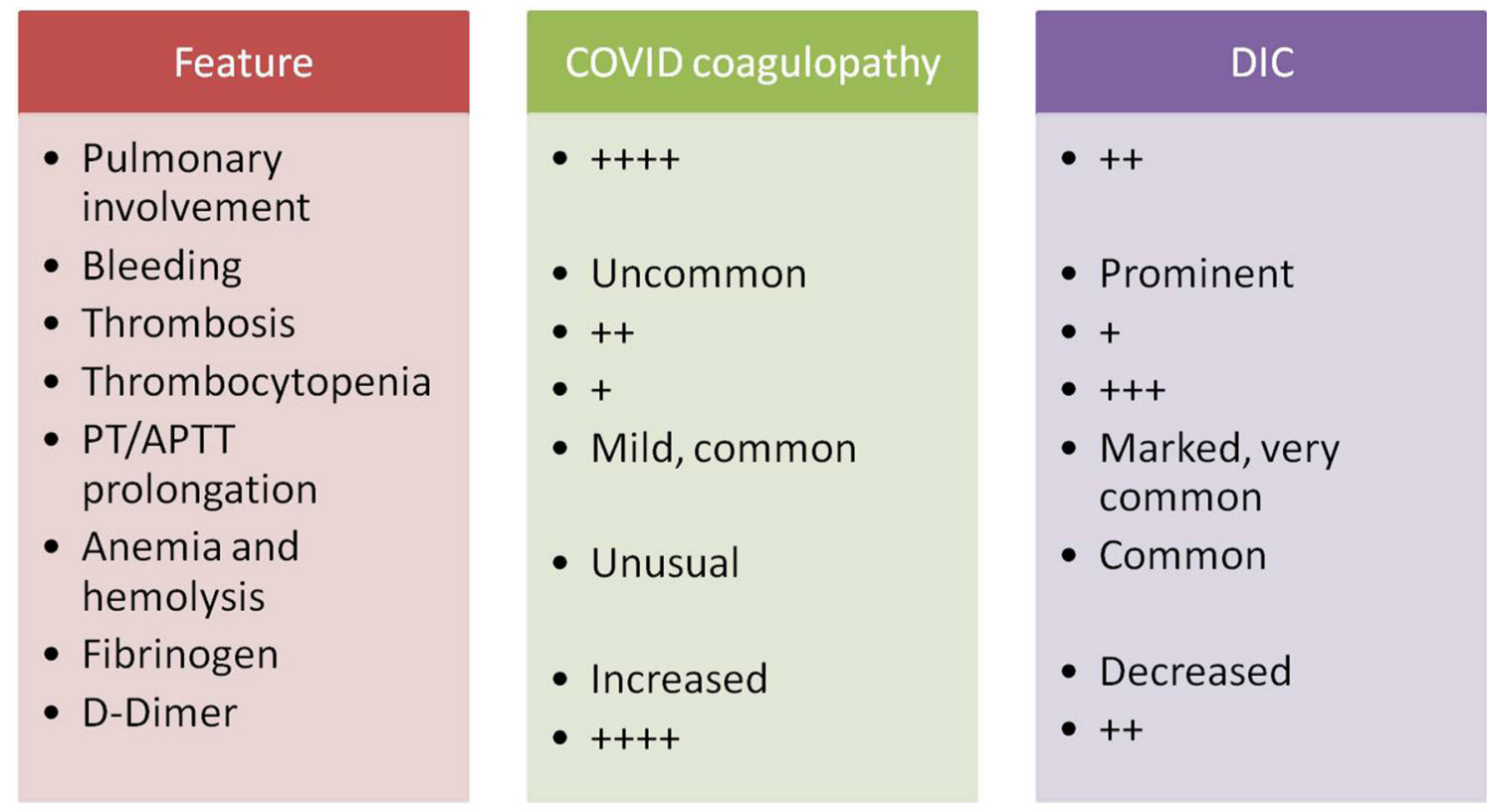

Fig. 2 Differences between COVID-19 coagulopathy from disseminated intravascular coagulation 
platelet count than non-COVID patients [19]. This is unlike sepsis where thrombocytopenia is an indicator of mortality due to sepsis [20]. Thrombocytopenia at threshold of $125 \times 10^{9} / \mathrm{L}$ was observed more frequently in COVID-19 non-survivors [17, 18].

This thrombocytopenia is multi-factorial in etiology including cytokine storm, possible direct cytopathic effect on marrow, immune mediated clearance of platelets due to formation of anti-platelet antibodies and lung injury causing platelet activation and consumption and lastly alteration of pulmonary capillary bed causing reduced lung megakaryocyte fragmentation and platelet production [21].

\section{Prothrombin Time (PT), Activated Partial Thromboplastin Time (APTT), Fibrinogen and D- Dimer}

Initial studies reported mild prolongation of PT in patients with severe disease requiring ICU admission and mortality $[4,8,9]$. It is important to remember that these mild prolongations may be missed if PT is expressed as PT ratio or PT\% rather than in seconds [8], as probably happened in studies when data was reported in these formats [22, 23]. APTT values did not correlate with severity of disease in most studies. Most consistent data reported was for D-dimer [4, 8, 9, 24, 25]. Elevated D-dimer value at admission is a predictor for both severity of COVID-19 [4, 9, 24] and mortality [8, 25, 26]. Various cut-offs have been determined to predict a higher risk of death in COVID-19 [25, 26] and for venous thromboembolism (VTE) [27]. The role of D-dimer to predict disease outcome was subsequently confirmed in a meta-analysis [28]. It is important to note that since D-dimer elevations in these hospitalized patients are not accurate predictor of subsequent VTE. The sensitivity, specificity and negative predictive value of elevated D-dimer at levels of $\geq 1.5 \mu \mathrm{g} /$ $\mathrm{mL}$ that predicted VTE were $85 \%, 88.5 \%$ and $94.7 \%$ respectively [27]. It is important to note that all the coagulation tests have been performed on different equipments using proprietary reagents and hence, cut-offs generated will have to be validated at each center. Table 1 discusses the role of D-dimer and Table 2 reflects the other routine coagulation parameters in COVID-19 patients. Fibrinogen is generally normal or elevated [29, 30] in these patients with a reduction in values reported only late in the course of disease when DIC sets in some patients [8].

\section{Viscoelastic Tests and a Procoagulant State}

The levels of Antithrombin (AT) have been found to be marginally reduced in COVID-19 patients compared to controls [31]. AT values decline in non-survivors by Day 7 when compared to survivors [8]. Factor VIII, vWF and
vWF ristocetin cofactor activity (vWF-RCoF) were evaluated in 11 patients and were increased at levels of $297 \mathrm{U} /$ $\mathrm{dL}(233-470), \quad 529 \mathrm{U} / \mathrm{dL}(210-863)$ and $387 \mathrm{U} /$ dL(195-550) respectively indicating possible endothelial dysfunction due to sepsis. In the same patient subset, AT and free protein $\mathrm{S}$ levels were marginally decreased while protein $\mathrm{C}$ was increased [30].

Limited studies on viscoelastic testing have shown a procoagulant profile rather than acute DIC in patients with COVID-19 (Table 3) [22, 29, 30]. This hypercoagulability may be attributed to endothelial dysfunction, elevated circulating platelet microparticles, neutrophil extracellular traps (NETs) and elevated inflammatory cytokines [30]. The impact of thromboprophylaxis to normalize the hypercoagulable state seen using the viscoelastic tests has largely not been documented. Only one of the studies that utilized the Quantra ${ }^{\circledR}$ hemostasis analyser where increasing thromboprophylaxis led to a reduction in the increased values of clot strength (CS), platelet contribution to clot strength and fibrinogen contribution to clot strength (FCS) [29]. However, only data from less than 100 patients in total has been reported in patients using various forms of viscoelastic testing [22, 29, 30]. It remains to be seen whether doing viscoelastic testing at baseline at the time of testing can identify patients who might go on to develop severe disease or thrombosis. The role of viscoelastic testing on management of thromboprophylaxis in COVID19 patients should be studied further.

\section{Antiphospholipid Antibodies (aPL) and Lupus Anticoagulant (LA)}

A report of three critical cases from China with aPL antibodies was published by Zhang et al. All the patients had a comorbid condition that predisposed them to severe disease and developed cerebral infarcts. Anticardiolipin (aCL) IgA antibodies and anti- $\beta 2$ glycoprotein-I IgA and IgG antibodies were reported in all patients but were negative for lupus anticoagulant (LA) [32]. It was interesting that in this case report, $\operatorname{IgA}$ antibody testing was performed for both aCL and anti- $\beta 2$ glycoprotein-I antibodies which are not a part of the diagnostic criteria for antiphospholipid syndrome [33] while the data on aCL IgG and IgM and anti- $\beta 2$ glycoprotein-I IgM antibodies is not reported. A series from France on 56 COVID-19 patients reported $45 \%$ positivity for LA while $\mathrm{aCL}$ and anti- $\beta 2$ glycoprotein-I (IgG/IgM) were seen in $10 \%$. Three patients were positive for both LA and one of the antiphospholipid antibodies tested [34]. This study has however, not reported data on thrombosis. In addition, it has not been mentioned whether DRVVT and LA sensitive PTT were performed before starting anticoagulant prophylaxis or not. 
Table 1 Correlation of D-dimer with mortality and severe disease

\begin{tabular}{|c|c|c|c|c|}
\hline & Patients (n) & $\begin{array}{l}\text { Severe versus non-severe } \\
\text { disease }\end{array}$ & $\begin{array}{l}\text { Non-survivors versus } \\
\text { survivors }\end{array}$ & Additional findings \\
\hline $\begin{array}{l}\text { Tang et al. } \\
{[8]}\end{array}$ & $\begin{array}{l}183(134 \\
\text { non- } \\
\text { survivors) }\end{array}$ & NR & $\begin{array}{l}2.12 \mu \mathrm{g} / \mathrm{mL}(0.77-5.27) \\
\quad \text { versus } 0.61 \mu \mathrm{g} / \mathrm{mL} \\
(0.35-1.29) \text { versus } \\
p<0.001\end{array}$ & $\begin{array}{l}\text { Incidence of DIC- } 71.4 \% \text { in non-survivors versus } \\
0.6 \% \text { in survivors }\end{array}$ \\
\hline $\begin{array}{l}\text { Huang et al. } \\
\text { [4] }\end{array}$ & $\begin{array}{l}41(13 \text { in } \\
\text { ICU) }\end{array}$ & $\begin{array}{l}2.4 \mathrm{mg} / \mathrm{L} ;(\mathrm{IQR} 0.6-14.4 \mathrm{mg} / \\
\mathrm{L}) \text { versus } 0.5 \mathrm{mg} / \mathrm{L} ;(\mathrm{IQR} \\
0.3-0.8 \mathrm{mg} / \mathrm{L} ; p=0.004)\end{array}$ & NR & \\
\hline $\begin{array}{l}\text { Wang et al. } \\
{[24]}\end{array}$ & $\begin{array}{l}138(36 \text { in } \\
\text { ICU) }\end{array}$ & $\begin{array}{l}4.14 \mathrm{mg} / \mathrm{L} ;(\mathrm{IQR} \\
1.91-13.2 \mathrm{mg} / \mathrm{L}) \text { versus } \\
1.66 \mathrm{mg} / \mathrm{L} ;(\mathrm{IQR} \\
1.01-2.85 \mathrm{mg} / \mathrm{L} ; p<0.001)\end{array}$ & NR & \\
\hline $\begin{array}{l}\text { Zhou et al. } \\
\text { [25] }\end{array}$ & $\begin{array}{l}191(54 \\
\text { non- } \\
\text { survivors) }\end{array}$ & NR & $\begin{array}{l}5.2 \mathrm{mg} / \mathrm{L} ;(\mathrm{IQR} \\
1.5-21.1 \mathrm{mg} / \mathrm{L}) \text { versus } \\
0.6 \mathrm{mg} / \mathrm{L} ;(\mathrm{IQR} 0.3-1.0- \\
\mathrm{mg} / \mathrm{L}) ; p<0.001\end{array}$ & $\begin{array}{l}\text { D-dimer } \geq 1.0 \mu \mathrm{g} / \mathrm{mL}: 81 \% \text { non-survivors versus } \\
24 \% \text { survivors; } p<0.0001 \text { and had a } \\
\text { multivariable odds ratio of } 18.42(p=0.003) \text { to } \\
\text { predict mortality }\end{array}$ \\
\hline $\begin{array}{l}\text { Zhang et al. } \\
{[26]}\end{array}$ & $\begin{array}{l}343(13 \\
\text { non- } \\
\text { survivors) }\end{array}$ & NR & $\begin{array}{l}4.76 \mu \mathrm{g} / \mathrm{mL}(2.99-11.9) \\
\quad \text { versus } 0.41 \mu \mathrm{g} / \mathrm{mL} \\
(0.15-0.69) ; p<0.001\end{array}$ & $\begin{array}{l}\text { D-dimer } \geq 2.0 \mu \mathrm{g} / \mathrm{mL} \text { at admission had a } \\
\text { sensitivity of } 92.3 \% \text { and specificity of } 83.3 \% \text { to } \\
\text { predict mortality; Hazard ratio: } 51.5,95 \% \text { CI } \\
12.9-206.7\end{array}$ \\
\hline $\begin{array}{r}\text { Middeldorp } \\
\text { et al. [23] }\end{array}$ & $\begin{array}{l}198(75 \text { in } \\
\text { ICU) }\end{array}$ & $\begin{array}{l}2.0 \mathrm{mg} / \mathrm{L}(0.8-8.1) \text { versus } \\
1.1 \mathrm{mg} / \mathrm{L}(0.7-1.6) \\
p=0.006\end{array}$ & & \\
\hline
\end{tabular}

$N R$ not reported, VTE venous thromboembolism, IQR inter quartile range

Table 2 Correlation of $\mathrm{PT}^{\mathrm{a}}$, $\mathrm{APTT}^{\mathrm{a}}$ with severity of COVID-19

\begin{tabular}{|c|c|c|c|c|}
\hline & Patients (n) & $\begin{array}{l}\text { Severe versus non-severe } \\
\text { disease }\end{array}$ & $\begin{array}{l}\text { Non-survivors versus } \\
\text { survivors }\end{array}$ & Additional findings \\
\hline $\begin{array}{l}\text { Tang } \\
\text { et al. } \\
{[8]}\end{array}$ & $\begin{array}{l}183(134 \\
\text { non- } \\
\text { survivors) }\end{array}$ & NR & $\begin{array}{l}\text { PT: } 15.5(14.4-16.3) \text { versus } \\
13.6(13.0-14.3), \\
p=<0.001 \\
\text { APTT } 44.8(40.2-51.0) \text { versus } \\
41.2(36.9-44.0), p=0.096\end{array}$ & $\begin{array}{l}\text { Fibrinogen and AT declined in non-survivors by day } \\
10 \text { and 14; also day } 7 \text { for AT } \\
\text { Expression of PT results as PT ratio miss the } \\
\text { significance }\end{array}$ \\
\hline $\begin{array}{l}\text { Huang } \\
\text { et al. } \\
\text { [4] }\end{array}$ & $\begin{array}{l}41(13 \text { in } \\
\text { ICU) }\end{array}$ & $\begin{array}{l}\text { PT: } 12 \cdot 2(11 \cdot 2-13 \cdot 4) \text { versus } \\
10 \cdot 7(9 \cdot 8-12 \cdot 1), p=0.012\end{array}$ & NR & \\
\hline $\begin{array}{l}\text { Wang } \\
\text { et al. } \\
\text { [24] }\end{array}$ & $\begin{array}{l}138(36 \text { in } \\
\text { ICU) }\end{array}$ & $\begin{array}{l}\text { PT: } 13.2 \text { (IQR 12.3-14.5) } \\
\quad \text { versus 12.9 (IQR } \\
\text { 12.3-14.5); } p 0.37 \\
\text { APTT: } 31.7 \text { (IQR 29.6-33.5) } \\
\quad \text { versus 30.4 (IQR 28.0-33.5), } \\
p=0.09\end{array}$ & NR & \\
\hline $\begin{array}{l}\text { Zhou } \\
\text { et al. } \\
{[25]}\end{array}$ & $\begin{array}{l}191(54 \\
\text { non- } \\
\text { survivors) }\end{array}$ & NR & $\begin{array}{l}\text { PT: } 12.1 \text { s (IQR 11.2-13.7) } \\
\text { versus } 11.4 \text { (IQR 10.4-12.6) } \\
p<0.0004\end{array}$ & $\begin{array}{l}\mathrm{PT} \geq 16 \mathrm{~s} \text { seen in in } 3 \% \text { survivors versus } 13 \% \text { non- } \\
\text { survivors, } p=0.016 \text { but lost significance on } \\
\text { multivariable analysis }\end{array}$ \\
\hline $\begin{array}{l}\text { Cui } \\
\text { et al. } \\
\text { [27] }\end{array}$ & $\begin{array}{l}81 \text { ( } 20 \text { had } \\
\text { VTE) }\end{array}$ & NR & NR & $\begin{array}{l}\text { APTT values in VTE significantly higher than } \\
\text { patients without VTE }\end{array}$ \\
\hline
\end{tabular}

$A T$ antithrombin, NR not reported, VTE venous thromboembolism, IQR inter quartile range

${ }^{\mathrm{a} P T}$ and APTT values reported in seconds 
Table 3 Viscoelastic tests in COVID-19

\begin{tabular}{llll}
\hline Study & No. of patients & Technique & Key findings \\
\hline $\begin{array}{c}\text { Spiezia } \\
\text { et al. } \\
\text { [22] }\end{array}$ & 22 ICU patients & $\begin{array}{c}\text { ROTEM with INTEM, EXTEM } \\
\text { and FIBTEM }\end{array}$ & $\begin{array}{c}\text { Significantly shorter CFT in INTEM and EXTEM } \\
\text { Significantly higher MCF in INTEM, EXTEM and FIBTEM }\end{array}$ \\
$\begin{array}{c}\text { Ranucci } \\
\text { et al. }\end{array}$ & 16 ICU patients & $\begin{array}{c}\text { Quantra Hemostasis analyser } \\
\text { using Quantra QPlus }{ }^{\circledR} \text { cartridge }\end{array}$ & $\begin{array}{c}\text { Increased CS, PCS, FCS in COVID-19 patients increasing } \\
\text { thromboprophylaxis caused reduction in CS, PCS and FCS }\end{array}$ \\
$\begin{array}{c}\text { [29] } \\
\begin{array}{c}\text { Panigada } \\
\text { et al. }\end{array}\end{array}$ & $\begin{array}{c}\text { 30 results from } \\
\text { [30] }\end{array}$ & $\begin{array}{c}\text { TEG with kaolin as activator and } \\
\text { heparinase }\end{array}$ & $\begin{array}{c}\text { R and K values were shorter in 50\% and 83\% while K angle and MA } \\
\text { were increased in 72\% and 83\% patients when compared to local } \\
\text { reference, decreased Lys30 }\end{array}$ \\
\hline
\end{tabular}

ROTEM rotational thromboelastometry, $C F T$ clot formation time, $M C F$ maximal clot firmness, $C S$ clot strength, $P C S$ platelet contribution to clot strength, FCS fibrinogen contribution to clot strength, TEG thromboelastography, $M A$ maximal amplitude

\section{Clinical Thrombosis}

As a result of CAC, patients of COVID-19 have been observed to have higher incidence of thrombosis including both VTE (DVT and PE), central venous catheter/arterial line associated thrombosis, thrombosis of extracorporeal circuits for continuous veno-venous hemofiltration $(\mathrm{CVVH})$ and extracorporeal membrane oxygenation (ECMO). The diagnosis of PE is challenging in these patients as symptoms of PE overlap with COVID-19. PE should be suspected if there is acute worsening of hypoxemia, blood pressure or tachycardia, and/or oxygen requirement and ventilatory settings are disproportionate to the severity of pneumonia on chest imaging. Even the diagnosis of DVT is difficult as the focus of care is on the respiratory system while the patients are in the ICU and the signs of DVT in the extremities may be missed. In addition, great amount of hospital resource is utilized in shifting these sicker patients to radiology units for carrying out computed tomography pulmonary angiogram (CTPA) and doppler ultrasound (USG) with associated risk of exposure and aerosolization The major contributory factors to thrombosis, in addition to those described above in pathology and prothrombotic state include ICU stay, central lines, CVVH, ECMO, limited mobility, comorbidities etc.

In most studies published evaluating symptomatic or asymptomatic VTE, overwhelmingly patients were from ICU and most of them were on prophylactic doses of LMWH (Table 4). Some studies have also included general ward patients, while some have screened for VTE in asymptomatic patients. As a result, incidence of symptomatic VTE is variable across studies. Llitjos et al. showed that incidence of thrombosis was lower if therapeutic doses of anticoagulation was used as prophylaxis (56\% vs $100 \%$ respectively, $p=0.03$ ) [35]. The 28 -day mortality of heparin users were lower than nonusers in
COVID-19 group with D-dimer $>3.0 \mu \mathrm{g} / \mathrm{mL}(32.8 \%$ vs $52.4 \%, p=0.017$ ) [19]. This suggests that even therapeutic anticoagulation is insufficient in some of these patients in the face of CAC.

The incidence of thrombosis varies from $7.7-14 \%$ in hospitalized patients to as high as $69 \%$ in ICU patients. Details are given in Table 4. Various risk factors identified from different studies are age and coagulopathy defined as prolonged PT $>3 \mathrm{~s}$ or APTT $>5 \mathrm{~s}$ [36]; duration of hospital stay (incidence at day 7, 14 and 21 being 16\%, 33\% and $42 \%$ respectively), ICU versus wards ( $47 \%$ vs $3.3 \%$ ), higher white blood cell count, higher neutrophil-lymphocyte ratio and a higher D-dimer level [23]; ICU versus general ward (16.7\% vs 6.4\%) [37]; D-dimer levels > $1570 \mathrm{ng} / \mathrm{mL}$ for asymptomatic DVT [38]. Not surprisingly, VTE has been associated with a higher risk of mortality with a hazard ratio (HR) of 2.7 (95\% CI 1.3-5.8) [23].

Helms et al. [39] compared 145 non-COVID-19 ARDS patients with 77 COVID-19 ARDS patients and confirmed that latter developed more thrombotic complications, mainly PE (11.7 vs $2.1 \%, p<0.008)$ and deranged coagulation parameters. Griffin et al. [40] described three patients of arterial thromboembolisms (stroke and popliteal arterial occlusion) in patients with COVID-19, treated with tPA, and/or antiplatelet therapy. Anecdotal reports of arterial thrombosis have also been published $[32,36]$.

\section{Possible Therapies}

In this section, we shall discuss about treatment strategies related to coagulopathy only. Considering the high incidence of thromboembolic phenomenon, it is prudent to put all patients admitted to ICU/HDU on thromboprophylaxis. VTE risk assessment tools like Padua prediction model have not been rigorously evaluated in COVID-19 patients. 
Table 4 Proven thrombosis in COVID patients

\begin{tabular}{|c|c|c|c|c|}
\hline & $\begin{array}{l}\text { No of } \\
\text { patients } \\
\text { (n) }\end{array}$ & Prophylaxis & $\begin{array}{l}\text { Incidence of VTE, arterial } \\
\text { thrombosis }\end{array}$ & Key findings \\
\hline $\begin{array}{l}\text { Klok et al. } \\
{[36]}\end{array}$ & $\begin{array}{l}184 \text { ICU } \\
\text { patients }\end{array}$ & Nadroparin & $\begin{array}{l}27 \%(95 \% \text { CI } 17-37) \text { VTE. } \\
3.7 \%(95 \% \text { CI } 0-8.2 \%) \\
\text { arterial }\end{array}$ & $\begin{array}{l}\text { PE common. Age (aHR 1.04), coagulopathy (aHR 4.1) are predictor } \\
\text { of thrombosis }\end{array}$ \\
\hline $\begin{array}{l}\text { Llitjos et al. } \\
{[35]}\end{array}$ & $\begin{array}{l}26 \mathrm{ICU} \\
\text { patients }\end{array}$ & Yes & $69 \%,(23 \% \mathrm{PE})$ & $\begin{array}{l}\text { Prophylaxis versus therapeutic ( } 100 \% \text { vs } 56 \% \text {, respectively, } \\
\quad p=0.03 \text { ) }\end{array}$ \\
\hline $\begin{array}{r}\text { Middeldorp } \\
\text { et al. [23] }\end{array}$ & $\begin{array}{l}198(75 \text { in } \\
\text { ICU) }\end{array}$ & Nadroparin & $20 \%$ (13\% symptomatic) & $\begin{array}{l}\text { ICU stay versus ward }(47 \%, 95 \% \text { CI } 36-58 \text { vs } 3.3 \%, 95 \% \text { CI } \\
1.3-8.1) \text {, higher WBC count, higher neutrophil-lymphocyte ratio } \\
\text { D-dimer were risk factors. Incidence increased with duration of } \\
\text { hospital stay }\end{array}$ \\
\hline $\begin{array}{l}\text { Lodigiani } \\
\text { et al. [37] }\end{array}$ & $\begin{array}{l}388(61 \text { in } \\
\text { ICU) }\end{array}$ & $\begin{array}{l}\text { All in ICU, } \\
75 \% \text { in } \\
\text { ward }\end{array}$ & $7.7 \%$ & ICU stay versus ward ( $16.7 \%$ vs $6.4 \%)$ \\
\hline $\begin{array}{l}\text { Demelo- } \\
\text { Rodriquez } \\
\text { et al. [38] }\end{array}$ & $\begin{array}{l}156 \text { non- } \\
\text { ICU } \\
\text { patients }\end{array}$ & Yes & $\begin{array}{l}14.7 \% \text {, only } 1 \text { proximal } \\
\text { DVT, } 7 \text { bilateral distal }\end{array}$ & $\begin{array}{l}\text { D-dimer levels }>1570 \mathrm{ng} / \mathrm{mL} \text { were associated with asymptomatic } \\
\text { DVT (OR 9.1; CI 95\% 1.1-70.1) }\end{array}$ \\
\hline $\begin{array}{l}\text { Helms et al. } \\
\text { [39] }\end{array}$ & $\begin{array}{l}150 \text { ICU } \\
\text { patients }\end{array}$ & & $\begin{array}{l}42.6 \%(16.7 \% \text { PE, circuit } \\
\text { clots in CRRT and ECMO) }\end{array}$ & $\begin{array}{l}>95 \% \text { elevated D-dimer and fibrinogen. No DIC. Higher incidence } \\
\text { as compared to non COVID ARDS, mostly PE }\end{array}$ \\
\hline
\end{tabular}

$V T E$ venous thromboembolism, $a H R$ adjusted hazard ratio, $D V T$ deep vein thrombosis, $P E$ pulmonary embolism, $D I C$ disseminated intravascular coagulation, ARDS acute respiratory distress syndrome, CRRT continuous renal replacement therapy, ECMO extracorporeal membrane oxygenation

Most recent ISTH guidelines continue to recommend thromboprophylaxis for all hospitalized patients instead of individualized risk assessment tools. The randomized trials are underway, but some of the key published studies available are discussed in Table 5.

Tang and colleagues reported one of the first studies to show benefit of anticoagulation in COVID-19 patients [41]. Even though day 28 mortality was similar between those on heparin and those without heparin $(30.3 \%$ vs $29.7 \%$, $p=0.910$ ), sub-group analysis showed that heparin was able to lower mortality in patients with sepsis-induced coagulopathy (SIC) score $\geq 4 \quad(40.0 \% \quad$ vs $64.2 \%$, $p=0.029)$ or D-dimer $>$ sixfold of upper limit of normal (32.8\% vs $52.4 \%, p=0.017)$. Testa et al. [42] showed $>6$ times higher C-trough levels of Direct acting oral anticoagulants (DOAC), given simultaneously with antivirals.

Table 5 Therapeutic interventions undertaken to prevent thrombosis

\begin{tabular}{|c|c|c|c|}
\hline Author & $\begin{array}{l}\text { Number of } \\
\text { patients (n) }\end{array}$ & Medicine under study & Results \\
\hline $\begin{array}{l}\text { Tang et al. } \\
\text { [41] }\end{array}$ & $\begin{array}{c}449 \text { (99 on } \\
\text { LMWH) }\end{array}$ & $\begin{array}{l}\text { Heparins versus no } \\
\text { heparin }\end{array}$ & $\begin{array}{l}\text { No difference on } 28 \text {-day mortality was found between heparin users and nonusers }(30.3 \% \\
\text { vs } 29.7 \%, p=0.910) \text {. But the } 28 \text {-day mortality of heparin users were lower than } \\
\text { nonusers in patients with SIC score } \geq 4(40.0 \% \text { vs } 64.2 \%, p=0.029) \text {, or } \\
\text { D-dimer }>\text { sixfold of upper limit of normal ( } 32.8 \% \text { vs } 52.4 \%, p=0.017)\end{array}$ \\
\hline $\begin{array}{l}\text { Testa et al. } \\
\text { [42] }\end{array}$ & 32 on DOACs & $\begin{array}{l}\text { Directly acting oral } \\
\text { anticoagulants } \\
\text { (DOACs) }\end{array}$ & C-trough levels were 6.14 times higher during hospitalization \\
\hline $\begin{array}{l}\text { Wang } \\
\text { et al. } \\
{[43]}\end{array}$ & 3 & tPA (alteplase) & Transient initial improvement in $\mathrm{PaO}_{2} / \mathrm{FiO}_{2}$ ratio (38-100\% improvement) \\
\hline $\begin{array}{l}\text { Liu et al. } \\
\text { [44] }\end{array}$ & 12 & Dipyridamole & Improved increased platelet and lymphocyte counts and decreased D-dimer levels \\
\hline $\begin{array}{c}\text { Diurno } \\
\text { et al. } \\
\text { [45] }\end{array}$ & 4 & Eculizumab & Reduction of C-reactive protein levels and clinical improvement \\
\hline
\end{tabular}

SIC sepsis-induced coagulopathy, $t P A$ tissue plasminogen activator 
Wang et al. [43] showed definite but transient improvement without bleeding in ventilatory parameters $\left(\mathrm{PaO}_{2} / \mathrm{FiO}_{2}\right)$ after treatment with short course of tPA (Alteplase) in ARDS due to COVID-19. Liu et al. [44] suggested potential benefit of adding dipyridamole. They suggested that dipyridamole can benefit patients by reducing viral replication, suppressing hypercoagulability, and enhancing immune recovery. Relating the pathogenesis to thrombotic microangiopathy, Diurno et al. [45] showed improved outcome with eculizumab, monoclonal antibody against C5 compliment used in cases of Paroxysmal nocturnal hemoglobinuria.

Choice of anticoagulant is heparin or LMWH during hospital stay. Limited data is available for use of DOACs or warfarin. Heparin could decrease the inflammatory response by blocking thrombin formation. Also, it may possess anti-viral properties by acting on SARS-CoV-2 surface receptor binding proteins and inhibiting viral attachment [46]. However, major issues with heparin are low antithrombin and high fibrinogen seen in CAC, both known to incur heparin resistance [47]. This suggests that prophylactic doses of LMWH or UFH could be less efficacious in severe CAC [48]. Shifting from prophylaxis to therapeutic doses in the absence of proven VTE, although common but is still not based on evidence. It may be considered in patients who are suspected thrombosis but not able to undergo imaging and those on ECMO. Testa et al. [42] suggested to stop DOAC and shift to heparins due to high drug levels of DOACs when given with antivirals or immunosuppressive therapy. Besides, there are issues of compromised absorption of oral medicine, concurrent renal dysfunction, and difficulty in measuring efficacy in sick ICU patients. They may be considered after discharge, for a total duration of 6 weeks of thromboprophylaxis.

\section{Academic Society Guidelines}

Several academic societies have come up with guidance for managing CAC. However, they have refrained from providing level of evidence with their recommendations as direct evidence is still lacking and data is evolving.

International society for thrombosis and hemostasis (ISTH) came with interim guidelines in March 2020 on recognition and management of coagulopathy in COVID19 based on ISTH DIC score [49]. Similarly, American Society of Hematology (ASH) mentions about management of CAC on its website [50]. A comparative analysis of these is shown in Table 6. Both guidelines mention about therapeutic LMWH in all hospitalized patients, unless contraindicated by $\mathrm{PC}$ or fibrinogen or active bleeding. VTE prophylaxis should be modified in obese or very thin patients and those with renal dysfunction. Patients with obesity should be considered for $50 \%$ rise in thromboprophylaxis dosage. Abnormal PT or APTT are not contraindications for pharmacological thromboprophylaxis. Mechanical thromboprophylaxis is recommended when pharmacological thromboprophylaxis is contraindicated. Therapeutic anticoagulation is not required unless VTE or atrial fibrillation is documented. Most of the guidelines are based on the premise that coagulopathy is a risk factor to multi-organ failure in patients with sepsis, so inhibiting thrombin generation is beneficial in reducing mortality [51]. Current guidelines recommend LMWH as preferred agent during hospitalization and DOAC for post discharge therapy for patients with proven thrombosis. At least three months of treatment is required for these patients [52].

Principles of blood transfusion are similar to septic coagulopathy with minor differences between guidelines issued by ASH and ISTH. Institution of blood component therapy is not recommended purely based on abnormal laboratory findings without the clinical indication of bleeding or requirement of invasive procedure or in those patients at a high risk of bleeding complications [50, 52, 53]. American College of Cardiology also advocates a similar policy with respect to thromboprophylaxis in hospitalized patients with COVID-19 and advised for careful assessment for incident thrombotic events. The duration of thromboprophylaxis is 6 weeks like other medical conditions [54]. Regarding therapeutic doses of anticoagulation for prophylaxis, British Thoracic Society (BTS) advocates risk stratification based on following factors [55]:

- Location of patient's care (e.g. critical care).

- Disease severity (e.g. need for CPAP, high oxygen requirements (e.g. $\mathrm{PaO}_{2} / \mathrm{FiO}_{2} \leq 40 \mathrm{kPa}(300 \mathrm{mmHg})$ ), SIC score $\geq 4$ ).

- D-dimer thresholds ( $>3000 \mu \mathrm{g} / \mathrm{L})$.

- Clinical features suggestive of possible VTE.

They also advocate shifting to LMWH if patients were previously on oral anticoagulants during hospital stay. After discharge, thromboprophylaxis should be considered for high risk VTE patients who were hospitalized. BTS suggest DOAC for thromboprophylaxis for upto 4 weeks. However, the recommended duration of post discharge prophylaxis ( 2 weeks, 4 weeks, or 6 weeks) and choice of agent (whether LMWH or DOAC) are still uncertain.

Recently published CHEST guidelines on CAC provide similar recommendations. They recommend standard dose LMWH as most preferred agent followed by UFH then DOAC for acutely ill and critical hospitalized patients with COVID-19. These guidelines recommend against antiplatelet for thromboprophylaxis and intermediate or full 
Table 6 Comparative analysis of academic society guidelines for COVID thrombosis

\begin{tabular}{|c|c|c|c|}
\hline Parameter & ISTH $[49,52]$ & ASH [50] & CHEST guidelines [56] \\
\hline Admission & $\begin{array}{l}\text { Prolonged PT, markedly raised } \\
\text { D-dimer }(\geq 3 \mathrm{ULN}), \\
\text { thrombocytopenia (platelet } \\
\left.\text { count }<100 \times 10^{9} / \mathrm{L}\right) \text { and } \\
\text { fibrinogen }<2.0 \mathrm{~g} / \mathrm{L}\end{array}$ & No comment & No comment \\
\hline Monitoring & PT, D-dimer, fibrinogen & $\begin{array}{l}\text { Platelet count, PT, APTT, D-dimer, and } \\
\text { fibrinogen }\end{array}$ & No comment \\
\hline $\begin{array}{l}\text { Prophylaxis with } \\
\text { LMWH }\end{array}$ & $\begin{array}{l}\text { All patients (including non-critically } \\
\text { ill) who require hospitalization. } \\
\text { Modification with weight and renal } \\
\text { function }^{\mathrm{a}}\end{array}$ & $\begin{array}{l}\text { Recommended for all hospitalized } \\
\text { COVID-19 patients }\end{array}$ & $\begin{array}{l}\text { Standard dose LMWH prophylaxis } \\
\text { recommended for all acutely ill and } \\
\text { critically ill hospitalized patients. } \\
\text { Heparins preferred }\end{array}$ \\
\hline $\begin{array}{l}\text { Contraindications to } \\
\text { prophylaxis }\end{array}$ & $\begin{array}{l}\text { Active bleeding and platelet } \\
\text { count }<25 \times 10^{9} / \mathrm{L}\end{array}$ & $\begin{array}{l}\text { Active bleeding, platelet } \\
\text { counts }<25 \times 10^{9} / \mathrm{L} \text {, or } \\
\text { fibrinogen }<0.5 \mathrm{~g} / \mathrm{L}\end{array}$ & Not specified for COVID-19 \\
\hline $\begin{array}{l}\text { Transfusion in } \\
\text { bleeding patient }\end{array}$ & $\begin{array}{l}\text { Maintain platelet count }>50 \times 10^{9} / \\
\mathrm{L}, \text { fibrinogen }>2 \mathrm{~g} / \mathrm{L} \text { and } \mathrm{PT} \\
\text { ratio }<1.5\end{array}$ & $\begin{array}{l}\text { Transfuse platelets if } \\
\text { count }<50 \times 10^{9} / \mathrm{L} \text { ), give plasma if } \\
\text { INR }>1.8 \text { and fibrinogen concentrate } \\
\text { or cryoprecipitate if } \\
\text { fibrinogen }<1.5 \mathrm{~g} / \mathrm{L}\end{array}$ & No comment \\
\hline $\begin{array}{l}\text { Transfusion in non } \\
\text { bleeding patient }\end{array}$ & $\begin{array}{l}\text { Fibrinogen }>2 \mathrm{~g} / \mathrm{L} \text { and platelet } \\
\text { count }>20 \times 10^{9} / \mathrm{L}\end{array}$ & No comment & No comment \\
\hline $\begin{array}{l}\text { Mechanical } \\
\text { thromboprophylaxis }\end{array}$ & $\begin{array}{l}\text { When pharmacological } \\
\text { thromboprophylaxis } \\
\text { contraindicated. Can be considered } \\
\text { together in sick/immobile patients }\end{array}$ & $\begin{array}{l}\text { When pharmacological } \\
\text { thromboprophylaxis contraindicated }\end{array}$ & $\begin{array}{l}\text { When pharmacological } \\
\text { thromboprophylaxis contraindicated. } \\
\text { No benefit of adding to pharmaco- } \\
\text { prophylaxis }\end{array}$ \\
\hline $\begin{array}{l}\text { Therapeutic } \\
\text { anticoagulation }\end{array}$ & $\begin{array}{l}\text { LMWH are preferred, duration is } \\
\text { minimum } 3 \text { months }\end{array}$ & VTE and atrial fibrillation & $\begin{array}{l}\text { LMWH/UFH preferred initially. } \\
\text { DOAC/warfarin if no drug } \\
\text { interactions. Outpatient with DOAC, } \\
\text { warfarin. Minimum } 3 \text { months } \\
\text { duration }\end{array}$ \\
\hline $\begin{array}{l}\text { Extended } \\
\text { anticoagulation }\end{array}$ & LMWH or DOAC for $14-30$ days ${ }^{b}$ & & Not advised \\
\hline Screening for DVT & Not needed ${ }^{b}$ & & Not recommended \\
\hline
\end{tabular}

$P T$ prothrombin time, $U L N$ upper limit of normal, INR international normalized ratio, VTE venous thromboembolism

${ }^{\mathrm{b}}$ From new ISTH guidelines (reference)

dose of LMWH. Extended thromboprophylaxis should be considered only for patients who are at low risk of bleeding. Mechanical prophylaxis is recommended only for those with contraindication to anticoagulants. For patients who develop VTE, these guidelines suggest initial LMWH (preferred) or UFH followed by continuation of same or shift to dabigatran or warfarin analogues. Thrombolytic therapy is recommended only for acute confirmed PE who show clinical deterioration. For non-hospitalized COVID patients who develop VTE, DOAC are preferred over LMWH for ease of administration and convenience to patients. Warfarin analogues can also be used for these patients after LMWH overlap. Overall duration of anticoagulation treatment should be at least three months [56].

\section{Conclusions}

COVID-19 associated coagulopathy is associated with high risk of morbidity and mortality and is a cause of concern especially in hospitalized patients. It is multifactorial in nature and manifests with deranged D-dimer, high fibrinogen and is different from DIC with respect to a low occurrence of thrombocytopenia, lack of severe thrombocytopenia, accompanied by only a mild prolongation of prothrombin time and activated partial thromboplastin time. It is important to remember that prothrombin time in these patients should be analyzed in seconds rather than as a ratio or percentage. Both venous and arterial thrombosis appear to be increased especially in sick patients and many of the thromboses may be subclinical in nature. Diagnosing 
pulmonary embolism in patients in ICU is challenging and high index of suspicion is warranted. Available evidence and guidelines recommend prophylactic anticoagulation with LMWH for all hospitalized patients. Anticoagulant and antiplatelet possibly improve by additional mechanisms (antiviral activity, improving thrombo-inflammation etc.) also in treatment of COVID-19 patients. Most of the available data is not based on randomized controlled trials, which have started recruitment only recently and are expected to guide us further into management of CAC.

\section{Compliance with Ethical Standards}

Conflict of interest The authors declare that they have no conflict of interests.

\section{References}

1. https://www.who.int/emergencies/diseases/novel-coronavirus2019/events-as-they-happen Accessed Mar 2020

2. Coronaviridae Study Group of the International Committee on Taxonomy of Viruses (2020) The species severe acute respiratory syndrome-related coronavirus: classifying 2019-nCoV and naming it SARS-CoV-2. Nat Microbiol 5(4):536-544. https://doi.org/ 10.1038/s41564-020-0695-Z

3. Cao W, Li T (2020) COVID-19: towards understanding of pathogenesis. Cell Res 30:367-369

4. Huang C, Wang Y, Li X, Ren L, Zhao J, Hu Y et al (2020) Clinical features of patients infected with 2019 novel coronavirus in Wuhan, China. Lancet 395:497-506

5. Mehta P, McAuley DF, Brown M, Sanchez E, Tattersall RS, Manson JJ, HLH Across Speciality Collaboration, UK (2020) COVID-19: consider cytokine storm syndromes and immunosuppression. Lancet 395:1033-1034

6. Chousterman BG, Swirski FK, Weber GF (2017) Cytokine storm and sepsis disease pathogenesis. Semin Immunopathol 39:517-528

7. Simmons J, Pittet JF (2015) The coagulopathy of acute sepsis. Curr Opin Anaesthesiol 28:227-236. https://doi.org/10.1097/ ACO.0000000000000163

8. Tang N, Li D, Wang X, Sun Z (2020) Abnormal coagulation parameters are associated with poor prognosis in patients with novel coronavirus pneumonia. J Thromb Haemost 18:844-847. https://doi.org/10.1111/jth.14768

9. Guan W, Ni Z, Hu Y, Liang WH, Ou CQ, He JX et al (2020) Clinical characteristics of coronavirus disease 2019 in China. N Engl J Med 382:1708-1720. https://doi.org/10.1056/ NEJMoa2002032

10. Tian S, Hu W, Niu L, Liu H, Xu H, Xiao SY (2020) Pulmonary pathology of early-phase 2019 novel coronavirus (COVID-19) pneumonia in two patients with lung cancer. J Thorac Oncol 15:700-704. https://doi.org/10.1016/j.jtho.2020.02.010

11. Menter T, Haslbauer JD, Nienhold R, Savic S, Hopfer H, Deigendesch N et al (2020) Post-mortem examination of COVID19 patients reveals diffuse alveolar damage with severe capillary congestion and variegated findings of lungs and other organs suggesting vascular dysfunction. Histopathology. https:// doi.org/10.1111/his.14134

12. Magro C, Mulvey JJ, Berlin D, Nuovo G, Salvatore S, Harp J et al (2020) Complement associated microvascular injury and thrombosis in the pathogenesis of severe COVID-19 infection: a report of five cases. Transl Res S1931-5244(20):30070. https://doi.org/ 10.1016/j.trsl.2020.04.007

13. Xu Z, Shi L, Wang Y, Zhang J, Huang L, Zhang C et al (2020) Pathological findings of COVID-19 associated with acute respiratory distress syndrome. Lancet Respir Med 8:420-422. https:// doi.org/10.1016/S2213-2600(20)30076-X

14. Wichmann D, Sperhake JP, Lütgehetmann M, Steurer S, Edler C, Heinemann A et al (2020) Autopsy findings and venous thromboembolism in patients with COVID-19: a prospective cohort study. Ann Intern Med. https://doi.org/10.7326/M20-2003.10. 7326/M20-2003

15 Fox SE, Akmatbekov A, Harbert JL, Li G, Brown Q, Vander Heide RS (2020) Pulmonary and cardiac pathology in Covid-19: the first autopsy series from New Orleans. Lancet Respir Med. https://doi.org/10.1101/2020.04.06.20050575

16. McGonagle D, Sharif K, O'Regan A, Bridgewood C (2020) The role of cytokines including interleukin-6 in COVID-19 induced pneumonia and macrophage activation syndrome-like disease. Autoimmun Rev 19:102537. https://doi.org/10.1016/j.autrev. 2020.102537

17. Yang X, Yang Q, Wang Y, Wu Y, Xu J, Yu Y, Shang Y (2020) Thrombocytopenia and its association with mortality in patients with COVID-19. J Thromb Haemost. https://doi.org/10.1111/jth. 14848.10 .1111 /jth. 14848

18. Liu Y, Sun W, Guo Y, Chen L, Zhang L, Zhao S et al (2020) Association between platelet parameters and mortality in coronavirus disease 2019: retrospective cohort study. Platelets 31:490-496. https://doi.org/10.1080/09537104.2020.1754383

19 Yin S, Huang M, Li D, Tang N (2020) Difference of coagulation features between severe pneumonia induced by SARS-CoV2 and non-SARS-CoV2. J Thromb Thrombolysis. https://doi.org/10. 1007/s11239-020-02105-8

20. Williamson DR, Albert M, Heels-Ansdell D, Arnold DM, Lauzier F, Zarychanski R, PROTECT collaborators, the Canadian Critical Care Trials Group, and the Australian, and New Zealand Intensive Care Society Clinical Trials Group (2013) Thrombocytopenia in critically ill patients receiving thromboprophylaxis: frequency, risk factors, and outcomes. Chest 144:1207-1215

21. Xu P, Zhou Q, Xu J (2020) Mechanism of thrombocytopenia in COVID-19 patients. Ann Hematol 99:1205-1208. https://doi.org/ 10.1007/s00277-020-04019-0

22. Spiezia L, Boscolo A, Poletto F, Cerruti L, Tiberio I, Campello E et al (2020) COVID-19-related severe hypercoagulability in patients admitted to intensive care unit for acute respiratory failure. Thromb Haemost. https://doi.org/10.1055/s-00401710018.10.1055/s-0040-1710018

23. Middeldorp S, Coppens M, van Happs TF, Foppen M, Vlaar AP, Muller MCA et al (2020) Incidence of venous thromboembolism in hospitalised patients with COVID-19. J Thromb Haemost. https://doi.org/10.1111/jth.14888.10.1111/jth.14888

24. Wang D, Hu B, Hu C, Zhu F, Liu X, Zhang J et al (2020) Clinical characteristics of 138 hospitalized patients with 2019 novel coronavirus-infected pneumonia in Wuhan, China. JAMA 323:1061-1069. https://doi.org/10.1001/jama.2020.1585

25. Zhou F, Yu T, Du R, Fan G, Liu Y, Liu Z et al (2020) Clinical course and risk factors for mortality of adult inpatients with COVID-19 in Wuhan, China: a retrospective cohort study. Lancet 395:1054-1062. https://doi.org/10.1016/S0140-6736(20)30566-3

26. Zhang L, Yan X, Fan Q, Liu H, Liu X, Liu Z, Zhang Z (2020) D-dimer levels on admission to predict in-hospital mortality in patients with Covid-19. J Thromb Haemost. https://doi.org/10. 1111/jth.14859.10.1111/jth.14859

27. Cui S, Chen S, Li X, Liu S, Wang F (2020) Prevalence of venous thromboembolism in patients with severe novel coronavirus pneumonia. J Thromb Haemost. https://doi.org/10.1111/jth. 14830.10.1111/jth.14830 
28. Lippi G, Favaloro EJ (2020) D-dimer is associated with severity of coronavirus disease 2019: a pooled analysis. Thromb Haemost 120:876-878. https://doi.org/10.1055/s-0040-1709650

29. Ranucci M, Ballotta A, Di Dedda U, Bayshnikova E, Dei Poli M, Resta M et al (2020) The procoagulant pattern of patients with COVID-19 acute respiratory distress syndrome. J Thromb Haemost. https://doi.org/10.1111/jth.14854.10.1111/jth.14854

30. Panigada M, Bottino N, Tagliabue P, Grasselli G, Novembrino C, Chantarangkul V et al (2020) Hypercoagulability of COVID-19 patients in intensive care unit a report of thromboelastography findings and other parameters of hemostasis. J Thromb Haemost. https://doi.org/10.1111/jth.14850

31 Han H, Yang L, Liu R, Liu F, Wu KL, Li J et al (2020) Prominent changes in blood coagulation of patients with SARS-CoV-2 infection. Clin Chem Lab Med. https://doi.org/10.1515/cclm2020-0188

32. Zhang Y, Xiao M, Zhang S, Xia P, Cao W, Jiang W et al (2020) Coagulopathy and antiphospholipid antibodies in patients with Covid-19. N Engl J Med 382(17):e38. https://doi.org/10.1056/ NEJMc2007575

33. Miyakis S, Lockshin MD, Atsumi T, Branch DW, Brey RL, Cervera $\mathrm{R}$ et al (2006) International consensus statement on an update of the classification criteria for definite antiphospholipid syndrome (APS). J Thromb Haemost 4:295-306

34. Harzallah I, Debliquis A, Drénou B (2020) Lupus anticoagulant is frequent in patients with Covid-19. J Thromb Haemost. https:// doi.org/10.1111/jth.14867

35. Llitjos JF, Leclerc M, Chochois C, Monsallier JM, Ramakers M, Auvray M et al (2020) High incidence of venous thromboembolic events in anticoagulated severe COVID- 19 patients. J Thromb Haemost. https://doi.org/10.1111/jth.14867.10.1111/jth.14867

36. Klok FA, Kruip MJHA, van der Meer NJM, Arbous MS, Gommers DAMPJ, Kant KM et al (2020) Incidence of thrombotic complications in critically ill ICU patients with COVID-19. Thromb Res. https://doi.org/10.1016/j.thromres.2020.04.013

37. Lodigiani C, Iapchino G, Carenzo L, Cecconi M, Ferrazzi P, Sebastian T et al (2020) Venous and arterial thromboembolic complications in COVID-19 patients admitted to an academic hospital in Milan, Italy. Thromb Res 191:9-14. https://doi.org/10. 1016/j.thromres.2020.04.024

38. Demelo-Rodríguez P, Cervilla-Muñoz E, Ordieres-Ortega L, Parra-Virto A, Toledano-Macías M, Toledo-Samaniego N, García-García A et al (2020) Incidence of asymptomatic deep vein thrombosis in patients with COVID-19 pneumonia and elevated D-dimer levels. Thromb Res 192:23-26. https://doi.org/10.1016/ j.thromres.2020.05.018

39 Helms J, Tacquard C, Severac F, Leonard-Lorant I, Ohana M, Delabranche X et al (2020) High risk of thrombosis in patients with severe SARS-CoV-2 infection: a multicenter prospective cohort study. Intensive Care Med. https://doi.org/10.1007/s00134020-06062-x

40. Griffin DO, Jensen A, Khan M, Chin J, Chin K, Parnell R et al (2020) Arterial thromboembolic complications in COVID-19 in low risk patients despite prophylaxis. Br J Haematol. https://doi. org/10.1111/bjh.16792.10.1111/bjh.16792

41. Tang N, Bai H, Chen X, Gong J, Li D, Sun Z (2020) Anticoagulant treatment is associated with decreased mortality in severe coronavirus disease 2019 patients with coagulopathy. J Thromb Haemost 18:1094-1099. https://doi.org/10.1111/jth.14817

42. Testa S, Prandoni P, Paoletti O, Morandini R, Tala M, Dellanoce C et al (2020) Direct oral anticoagulant plasma levels' striking increase in severe COVID-19 respiratory syndrome patients treated with antiviral agents: the Cremona experience. J Thromb Haemost. https://doi.org/10.1111/jth.14871.10.1111/jth.14871

43. Wang J, Hajizadeh N, Moore EE, McIntyre RC, Moore PK, Veress LA et al (2020) Tissue plasminogen activator (tPA) treatment for COVID-19 associated acute respiratory distress syndrome (ARDS): a case series. J Thromb Haemost. https://doi. org/10.1111/jth.14828.10.1111/jth.14828

44. Liu X, Li Z, Liu S, Chen Z, Zhao Z, Huang Y-Y et al (2020) Therapeutic effects of dipyridamole on COVID-19 patients with coagulation dysfunction. https://doi.org/10.1101/2020.02.27. 20027557

45. Diurno F, Numis FG, Porta G, Cirillo F, Maddaluno S, Ragozzino A et al (2020) Eculizumab treatment in patients with COVID-19: preliminary results from real life ASL Napoli 2 Nord experience. Eur Rev Med Pharmacol Sci 24(7):4040-4047. https://doi.org/10. 26355/eurrev_202004_20875

46. Mycroft-West CJ, Su D, Elli S et al (2020) The 2019 coronavirus (SARS-CoV-2) surface protein (spike) S1 receptor binding domain undergoes conformational change upon heparin binding. https://doi.org/10.1101/2020.02.29.971093

47. Harr JN, Moore EE, Chin TL, Ghasabyan A, Gonzalez E, Wohlauer MV et al (2014) Postinjury hyperfibrinogenemia compromises efficacy of heparin-based venous thromboembolism prophylaxis. Shock 41:33-39. https://doi.org/10.1097/SHK. 0000000000000067

48. Barrett CD, Moore HB, Yaffe MB, Moore EE (2020) ISTH interim guidance on recognition and management of coagulopathy in COVID-19: a comment. J Thromb Haemost. https://doi. org $/ 10.1111 /$ jth. $14860.10 .1111 /$ jth. 14860

49. Thachil J, Tang N, Gando S, Falanga A, Cattaneo M, Levi M et al (2020) ISTH interim guidance on recognition and management of coagulopathy in COVID-19. J Thromb Haemost 18:1023-1026. https://doi.org/10.1111/jth.14810

50. https://www.hematology.org/covid-19/covid-19-and-coagulo pathy Accessed May 2020

51. Iba T, Levy JH, Warkentin TE et al (2019) Diagnosis and management of sepsis-induced coagulopathy and disseminated intravascular coagulation. J Thromb Haemost 17(11):1989-1994

52. Spyropoulos AC, Levy JH, Ageno W, Connors JM, Hunt BJ, Iba $\mathrm{T}$, Subcommittee on Perioperative, Critical Care Thrombosis, Haemostasis of the Scientific, Standardization Committee of the International Society on Thrombosis, Haemostasis+ (2020) Scientific and standardization committee communication: clinical guidance on the diagnosis, prevention and treatment of venous thromboembolism in hospitalized patients with COVID-19. J Thromb Haemost. https://doi.org/10.1111/jth.14929

53 Wada H, Thachil J, Di Nisio M, Mathew P, Kurosawa S, Gando S et al (2013) Guidance for diagnosis and treatment of DIC from harmonization of the recommendations from three guidelines. The scientific standardization committee on DIC of the international society on thrombosis haemostasis. J Thromb Haemost 11:761-767. https://doi.org/10.1111/jth.12155

54. Bikdeli B, Madhavan MV, Jimenez D, Chuich T, Deryfus I, Driggin E et al (2020) COVID-19 and thrombotic or thromboembolic disease: implications for prevention, antithrombotic therapy and follow up. J Am Coll Cardiol S0735-1097(20):35008-35017

55. Condliffe R, Bunclark K, Hurdman J, Kiely D, MacLean R, Price $\mathrm{L}$ et al. BTS guidance on venous thromboembolic disease in patients with COVID-19.https://brit-thoracic.org.uk/about-us/ covid-19-information-for-the-respiratory-community

56. Moores LK, Tritschler T, Brosnahan S, Carrier M, Collen JF, Doerschug K et al (2020) prevention, diagnosis, and treatment of VTE in patients with COVID-19: CHEST guideline and expert panel report [published online ahead of print, 2020]. Chest S0012-3692(20)31625-1

Publisher's Note Springer Nature remains neutral with regard to jurisdictional claims in published maps and institutional affiliations. 